\title{
A percepção dos conselheiros de Botucatu, São Paulo sobre o processo de qualificação em saúde
}

\author{
Violeta Campolina Fernandes, Regina Stella Spagnuolo
}

\begin{abstract}
Resumo
A participação comunitária é assegurada pela Constituição Federal e regulada pela Lei n. 8.142/90, em que ocorre mediante a participação dos atores sociais nas Conferências e Conselhos de Saúde, nas três esferas de governo. Este estudo insere-se no contexto da participação social de conselheiros de saúde e no fortalecimento de suas práticas. Conhecer a percepção dos conselheiros municipais de saúde em relação ao processo de qualificação em saúde no município de Botucatu, São Paulo. Trata-se de pesquisa qualitativa, alicerçada no método Estudo de caso, realizada com dezesseis conselheiros municipais de saúde sendo, dois representantes da administração pública (gestores), dois prestadores de serviço, cinco trabalhadores da saúde e sete representantes dos usuários. Foi realizada entrevista orientada por roteiro semiestruturado e os dados analisados à luz da Análise de Conteúdo representacional temática. A análise revelou a seguinte categoria: "Percepções dos conselheiros sobre a sua qualificação em saúde". No que se refere à realização de qualificações, pode-se verificar que a maioria dos participantes $(62,5 \%)$ não a recebeu para exercer as suas funções no conselho. No entanto, os participantes que relataram não receber qualificações, sentem falta de um auxílio formal para, principalmente, sanar dúvidas e melhorar a compreensão sobre os assuntos importantes do conselho. Pôde-se observar que os participantes, em sua maioria, desejam receber qualificação principalmente sobre as funções do conselheiro, pois, acreditam que tal tema é de extrema importância para melhora da atuação. Entretanto, uma parcela $(37,5 \%)$ informou ter realizado qualificações em gestões anteriores a do conselho vigente em que foram trabalhados temas relativos ao funcionamento do conselho. É interessante considerar que a maioria que recebeu qualificação específica pertence ao segmento dos usuários, ao passo que nenhum conselheiro do segmento gestor e prestador a recebeu e apenas dois conselheiros do segmento trabalhadores foi qualificado. Sendo assim, menos da metade dos participantes receberam qualificação formal para atuação de conselheiro, evidenciando um vazio de educação permanente, ou seja, há uma distância do que realmente é com o que deveria ser. Constatou-se a necessidade dos gestores municipais juntamente com os representantes de cada categoria criar ambientes propícios para difusão do conhecimento. Para tanto, se faz necessário democratizar a comunicação e a informação. Recomenda-se uma educação permanente por meio de oficinas, rodas de conversa e cursos formais e específicos, para que a formação e mobilização aconteçam de maneira articulada e interdependente numa perspectiva de produção coletiva de saúde. Como fatores limitantes, apresenta-se a locoregionalização do cenário estudado, porém, infere-se que os resultados possam ser replicados em municípios semelhantes, auxiliando a elaboração de políticas públicas locais.
\end{abstract}

Descritores: Conselhos de Saúde; Participação Social; Educação. 